\title{
ПОЛІТИЧНА ПСИХОЛОГІЯ
}

\author{
УДК 159.922.1:364-37.035 \\ DOI https://doi.org/10.32840/2663-6026.2019.4-2.29
}

B. M. Timяes

кандидат психологічних наук, доцент, доцент кафедри практичної психології Національний педагогічний університет імені М. П. Драгоманова

\section{ОСНОВНІ НАПРЯМИ ФОРМУВАННЯ ПСИХОЛОГІЧНОЇ РЕЗИСТЕНТНОСТІ ДО ВПЛИВУ АГРЕСИВНОГО ІНФОРМАЦІЙНОГО СЕРЕДОВИЩА}

У статті на основі аналізу сучасного рівня інформаційно-психологічного впливу на Україну з боку Російської Федерації та відповідних наукових розробок у иій галузі констатується фракт ведення проти нашої країни повноцінної інформаційної війни, а також недостатньої готовності з боку держави та суспільства чинити їй опір. На цій підставі визначається нагальна необхідність створення в Україні цілісної ефективної системи протидії агресивному інформаційному впливу. Дослідження сучасних підходів до визначення структури інфрормаційної війни дало змогу виокремити в їі складі психологічний компонент як безпосередній об'єкт спрямування зусиль психологічної науки.

Аналіз цієї складової частини дав можливість виділити три групи психологічних чинників, що впливають на схильність людини підпадати під вплив агресивного інформаційного середовища або чинити йому опір. Це індивідуально-психологічні, соціально-психологічні й етнопсихологічні чинники. До першої групи віднесені особистісні якості, які спонукають людину до конформної поведінки, до другої- чинники, що зумовлені рівнем розвитку суспільства, і до третьої- відповідні риси національного менталітету.

На основі даної класифрікації, відповідно до наведених вище груп чинників, розроблено напрями формування психологічної резистентності особистості до інформаційно-пропагандистського впливу й умови їх ефрективної реалізації. Першим напрямом визначено фформування індивідуальної психологічної резистентності, головним змістом якого є розвиток здатності індивіда до критичного мислення. Другий напрям - формування психологічної резистентності на соціальному рівні - передбачає, 3 одного боку, просвітницьку діяльність держави і суспільних організацій щодо надання громадянам відповідної інформації про стан розвитку суспільства та його перспективи, із другого - реформування державних інституцій відповідно до актуального рівня розвитку суспільства. Третім напрямом є фоормування психологічної резистентності на рівні національної свідомості, провідним змістом роботи тут передбачається дослідження та культивування тих рис національного характеру, які допомагають формувати критичне сприйняття інформації, самостійність мислення і поведінки, прагнення до успіху та конкурентної боротьби.

Ключові слова: інформаційна війна, психологічний опір, конформізм, спіральна динаміка, національний менталітет.

Постановка проблеми. Протягом останніх п'яти років на Україну з боку Російської Федерації здійснюється потужний інформаційно-пропагандистський вплив, який за силою, масштабом i рівнем агресивності повною мірою відповідає поняттю «інформаційна війна». Цей вплив передував реальним бойовим діям на сході країни і супроводжує їх нині. Він $є$ однією з основних передумов анексії Росією Кримського півострова й окупації окремих районів Донецької й Луганської областей, коли тисячі цивільних людей виходили на проросійські мітинги, блокували військові частини та перешкоджали пересуванню військової техніки, а дві третини службовців українських силових структур (Збройні сили України,
Міністерство внутрішніх справ, Служба безпеки України тощо) у Криму перейшли на бік ворога.

Наша держава, її провідні інституції, як і українське суспільство загалом, виявилися абсолютно неготовими чинити опір агресії противника в інформаційному просторі. Доказом цього, зокрема, може слугувати той феномен, що і сьогодні, на шостому році війни, значна кількість наших громадян тією чи іншою мірою не визнає або заперечує фракт війни і не вбачає в Росії країни-агресора.

Отже, можна з повною мірою відповідальності констатувати нагальну потребу створення в Україні ефективної системи протидії інформаційно-пропагандистському впливу противника. 
Аналіз останніх досліджень і публікацій. Питання правил і особливостей ведення інфоормаційних війн, як і протидії їм, вивчається ще із часів Сунь Цзи та його праці «Мистецтво війни» (кінець VI - початок V ст. до н. е.). Але останнім часом, у зв'язку з різким зростанням різноманітності, поширеності, доступності, отже, і ролі засобів масової інформації ця проблема стала предметом особливої уваги дослідників. Відповідно до них, як зазначає С. Шпилик [12], інформаційна війна - це:

- вплив на цивільне населення і (або) військовослужбовців іншої держави шляхом поширення певної інформації. Термін «інформаційно-психологічна війна» запозичений зі словника військових кіл Сполучених Штатів Америки (далі США). Переклад цього терміна ("information and psychological warfare") англійською мовою може звучати і як «інфрормаційне протиборство», і як «інформаційна, психологічна війна», залежно від контексту конкретного офріційного документа або наукової публікації [9];

- цілеспрямовані дії, початі для досягнення інформаційної переваги шляхом завдавання шкоди інформації, інфоормаційним процесам та інформаційним системам противника за одночасного захисту власної інформації, інформаційних процесів та інформаційних систем [5];

- усеосяжна, цілісна стратегія, зумовлена зростанням значущості й цінності інформації в питаннях командування, управління, політики, економіки та суспільного життя [4];

- збирання компромату на конкурентів і його планомірне використання [7];

- явні та приховані цілеспрямовані інформаційні дії систем одна на одну з метою отримання зиску в матеріальній сфрері [11];

- нова форма боротьби сторін, у якій використовуються спеціальні способи та засоби, що впливають на інформаційне середовище супротивника й захищають власне в інтересах досягнення стратегічних цілей війни [2].

Але в будь-якому разі мета інформаційної війни - послабити моральні та матеріальні сили супротивника або конкурента й посилити власні. Вона передбачає заходи пропагандистського впливу на свідомість людини [12].

Мета статті - на основі аналізу психологічних чинників, що впливають на здатність людини піддаватися впливу агресивного інформаційного середовища або чинити йому опір, визначити й обґрунтувати основні напрями фоормування в особистості психологічної резистентності до такого роду впливів.

Виклад основного матеріалу. Згідно з визначенням Інституту національно-стратегічних досліджень США, інфрормаційна війна включає сім компонентів, як-от:
1. Стратегія і тактика нейтралізації органів управління противника (командна війна).

2. Розвідувальна війна.

3. Електронна війна.

4. Психологічна війна.

5. Комп'ютерна війна.

6. IB в економічній сорері.

7. Інформаційний тероризм [8].

Отже, психологічна війна $є$ невід'ємною складовою частиною війни інформаційної, і цей факт змушує замислитися над створенням у державі ефрективної цілісної системи інформаційної безпеки загалом і місця в ній психолога зокрема.

Аналізуючи психологічну складову частину інформаційної війни та проблеми, що неминуче виникають під час розбудови зазначеної вище системи інформаційної безпеки, ми визначили деякі суто психологічні чинники, які тією чи іншою мірою впливають на схильність людини підпадати під вплив агресивного інфоомаційного середовища або чинити йому опір. Для зручності подальшої роботи із цими чинниками ми поєднали їх у три групи, а саме:

а) індивідуально-психологічні;

б) соціально-психологічні;

в) етнопсихологічні, або культуральні.

До першої групи віднесені ті особистісні якості, які спонукають людину до конформної (або нонконформної) поведінки і таким чином сприяють або перешкоджають впливу засобів ведення інформаційної війни на її психіку.

Друга група містить чинники, що зумовлені рівнем розвитку певного суспільства.

третя група психологічних чинників охоплює відповідні риси національного менталітету, які впливають на здатність особистості підпадати під вплив агресивного інформаційного середовища або чинити йому опір.

Виходячи з даної класифікації, видається доцільним визначити напрями фоормування психологічної резистентності особистості до інформаційно-пропагандистського впливу відповідно до наведених вище груп чинників. Отже, отримуємо три основні напрями, кожен з яких розглянемо докладніше.

Перший напрям - формування індивідуальної психологічної резистентності. Для цього варто конкретизувати ті чинники, що викликають в особистості прояви конформної поведінки. Зазначимо одразу, що власне конформізм - цілком природне психічне утворення, що сформувалося на самому початку існування людства i дозволило (та й по сьогодні дозволяє) індивідам більш-менш успішно співіснувати у спільноті.

Проблема полягає у відсутності (або складності) свідомого контролю за конформними проявами i, як наслідок, - у неспроможності людини чинити опір зовнішньому впливу. 
Ще в 1951 р. американський психолог Соломон Аш поставив свій відомий експеримент щодо дослідження впливу групової думки на індивіда. Більшість піддослідних, згідно 3 отриманими результатами, яскраво проявили конформну поведінку. Його дослідження неодноразово повторювалося іншими спеціалістами, проте результати залишались незмінними. У 1971 р. радянські психологи спробували довести, що «людина нової формації» вестиме себе принципово по-іншому, але їхня гіпотеза не була підтверджена практично.

У 2015 р. в Україні репортер І. Павлюк і психіатр О. Чабан повторили експеримент С. Аша, значно розширивши його, що дозволило не тільки констатувати конформні поведінкові прояви окремих індивідів, але й конкретизувати причини, які ïx спровокували. Експерименту присвячений документальний фрільм «Обыкновенные зомби: какработает ложь». Серед основних причин були визначені такі:

- острах особи виглядати дурнем в очах інших;

- прагнення поваги й ушанування 3 боку незнайомих людей;

- перебування в суб'єктивно небезпечній ситуації та переживання почуття тривоги;

- відчуття невпевненості в завтрашньому дні.

Усі ці чинники дозволяють відносно легко маніпулювати свідомістю людей.

Лише незначний відсоток піддослідних виявив здатність чинити опір потужному зовнішньому впливу. Це були особи, які, по-перше, мали звичку ставити під сумнів будь-яку інфрормацію, по-друге, не боялися помилитися і, навіть більше, завчасно залишали за собою право на помилку.

Отже, можна зробити висновок, що формування індивідуальної психологічної резистентності до агресивного інформаційного впливу головним чином полягає в розвитку здатності індивіда до критичного мислення, що і буде змістом першого напряму.

Другий напрям - формування психологічної резистентності на соціальному рівні.

Тривалий час (з кінця XIX - початку XXст.) психологами та соціологами вважалося, чим примітивнішою $є$ спільнота, тим легше вона піддається зовнішньому впливу. Відомим прикладом такого дослідження може слугувати популярна робота Ґюстава Ле Бона «Психологія мас» [6]. На жаль, після Другої світової війни дослідження людських спільнот, націй, рас і особливо відмінностей між ними були поступово згорнуті. Сьогодні ж, на початку XXI ст., вони і взагалі вважаються неполіткоректними.

Проте, як показують події останніх років у світі, навіть народи найрозвиненіших країн не позбавлені проявів соціального інфрантилізму. На наш погляд, наукове вивчення цього феномену має значні перспективи, але це вже тема іншого дослі- дження. Ми ж на даному етапі лише констатуємо фракт наявності різниці між рівнями розвитку людських спільнот і, відповідно, різниці у схильності цих спільнот до більш або менш критичного сприйняття інформації.

У нас природно виникає потреба в певній системі, що дозволить достатньо об'єктивно визначити рівень розвитку спільноти, класифрікувати та конкретизувати прояви суспільної думки й групового настрою, а також дати змогу спрогнозувати їх перебіг.

На нашу думку, системою, яка найбільш повно відповідає цим вимогам, є концепція видатного американського психолога XX ст. К. Грейвза. Продовжуючи дослідження А. Маслоу в руслі гуманістичної психології та розвиваючи його концепцію ієрархії людських потреб, у другій половині минулого століття К. Грейвз на основі величезної кількості експериментальних і статистичних даних сформулював унікальну модель розвитку всіх динамічних, тобто біосоціальних систем (від психіки людини до країн і народів). Його роботи були розвинені Д. Беком і К. Кованом, які побудували на їх базі новий напрям у психології, що дістав назву «Спіральна динаміка» [1].

На сьогодні вона є цілком самостійною концепцією, що дозволяє ефеетивно досліджувати будьяку динамічну систему і визначати актуальний стан її розвитку (рис. 1).

Сутність Спіральної динаміки полягає в тому, що еволюція будь-якої живої системи відбувається ідентичним шляхом, від одного рівня існування до іншого. Кожний такий етап має свої унікальні характеристики, які проявляються в кардинальних змінах пріоритетів, цінностей, поглядів людини або суспільства і дозволяють чітко класифікувати наявний рівень розвитку зазначеної системи.

На сьогодні відомо вісім рівнів існування.

1. «Мисливці-самотники». Експресивний тип. Мета - біологічне виживання. Працюють лише базові інстинкти - голод, розмноження тощо.

2. «Плем'я». Жертовний тип: індивідуальність приноситься в жертву виживанню племені. Мета безпека, виживання племені, сім'ї. Світ сприймається наповненим духами, яким треба догоджати.

3. «Боги та герої». Експресивний. Спроба гіперреалізації себе, імпульсивно, будь-якою ціною. Мета - особиста влада, розширення сфери контролю. Світ - це джунглі, виживає найсильніший. Доба великих мандрівників і героїв.

4. «Жертва заради ідеї». Жертовний. Пожертвувати чимось, щоб отримати винагороду пізніше. Власні бажання приносяться в жертву ідеї, вищому порядку. Почуття обов'язку. Мета - стабільність, порядок, дотримання ритуалів.

5. «Велика гра». Експресивний. Обдумані прояви себе, зокрема й за рахунок інших. Реалізація себе в конкуренції з іншими, причому власне про- 


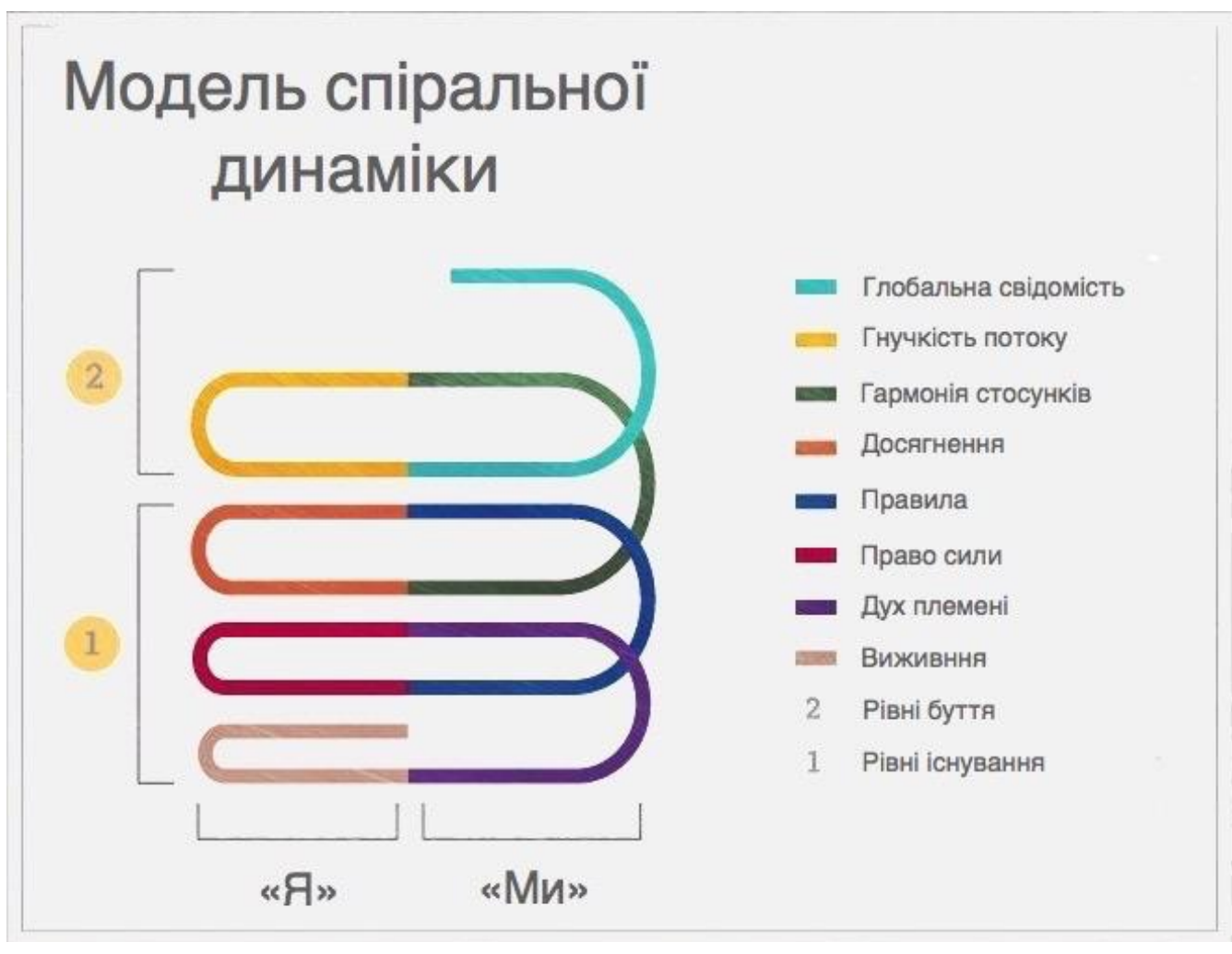

Рис. 1. Модель Спіральної динаміки (за К. Грейвзом)

цес ціниться вище за результат. Тому, хто програв, можуть повернути програш, щоб зіграти ще раз. Виникає професійний спорт, конкурси краси тощо. Мета - успіх, вплив.

6. «Людина вища понад усе». Жертовний. Жертвую одним зараз заради іншого зараз же. Життєве кредо - безкоштовних тістечок не буває. Увага до потреб інших людей. 3'являється концепція екології. Мета - гармонія, взаємне зростання, співробітництво.

7. «Інтеграція». Експресивний. Виражаю себе, але не за рахунок інших. Прагнення до інтеграції конфліктів, задоволення всіх потреб. Мета - незалежність, свобода, гідність, інтеграція до глобальної системи. Системний підхід, урахування контексту.

8. «Глобальна свідомість». Цей рівень поки що недостатньо вивчений. Жертовний тип. Пристосування себе до базових принципів устрою світу. Глобальне суспільство, сприйняття людства як цілого, інтеграція на рівні культур [3, с. 114].

Згідно із цією концепцією, передові західноєвропейські країни нині перебувають на шостому ціннісному рівні («Людина понад усе»), а деякі вже виходять на сьомий («Інтеграція»). Про це свідчать такі прояви, як суспільна толерантність, прагнення врахувати інтереси всіх сторін, а суперечки вирішувати шляхом пошуку консенсусу, урешті-решт, та сама глобалізація, щодо доцільності якої сьогодні точиться так багато дискусій. США в цьому сенсі дещо відстають, але такі об'єктивні показники, як прагнення до порозуміння, формування командної взаємодії, увага до потреб кожної людини й інші, дозволяють стверджувати, що і там відбувається перехід із п'ятого («Велика гра») на шостий ціннісний рівень.

Російська Федерація впевнено посідає четвертий рівень («Жертва заради ідеї»): закон і традиції визначають правила поведінки, що базуються на абсолютних принципах; імпульсивність обмежується почуттям провини; наявні і цінні жорстка ієрархія та влада авторитету.

Наше суспільство, за Спіральною динамікою, сьогодні перебуває на переході від четвертого («Жертва заради ідеї»), характерного для майже всіх пострадянських країн, до п'ятого ціннісного рівня («Велика гра»), якому властиві такі прояви: зміни і прогрес - необхідні атрибути природи речей; розвиток через пошук найкращих рішень; маніпулювання ресурсами довкілля для досягнення добробуту; ідеалізація успіху; конкуренція тощо. Цей процес характеризується зростанням індивідуальної ініціативи, прагненням до особистого успіху, конкуренцією, готовністю до ризику й іншими чинниками.

Кожний рівень розвитку має свої переваги і недоліки.

Перевагами четвертого рівня $є$ висока структурованість і згуртованість суспільства, об'єднаного традиційними цінностями, поглядами й ідеалами. Недоліками - ригідність і неспроможність вчасно 
реагувати на швидкі зміни ситуації, нагальна потреба в авторитетному керівникові.

До переваг п'ятого рівня можна віднести високу динамічність, індивідуальну ініціативність, активність і конкурентну боротьбу. До недоліків роз'єднаність і розпорошеність суспільства, певний соціальний егоїзм. Крім того, варто враховувати наслідки власне процесу переходу з одного рівня на інший, що само є значною кризою.

Отже, основним змістом роботи на другому напрямі $\epsilon, ~ з$ одного боку, просвітницька діяльність держави і суспільних організацій щодо надання громадянам відповідної інформації про стан розвитку суспільства та його найближчі та віддалені перспективи. А із другого боку якнайшвидше реформування державних інституцій відповідно до актуального рівня розвитку суспільства.

Третій напрям - формування психологічної резистентності на рівні національної свідомості.

Цей напрям видається найскладнішим тому що, по-перше, системні дослідження в галузі української ментальності за останні сто років практично не проводилися. По-друге, дослідження національних особливостей нині «не у тренді» і світової психологічної науки. І, по-третє, в українському суспільстві сильно даються взнаки результати кількасотрічної пропаганди тотожності українського і російського народів (концепції «єдиного народу» і «братніх народів»).

Натомість російські спецслужби добре розуміють значення ментального чинника і спираються на нього, організовуючи та проводячи інформаційно-пропагандистський вплив на українське суспільство. Про це свідчать результати новітніх вітчизняних досліджень. Так, М. Горовий у своїй монографії «Соціокультурні механізми формування ментального імунітету проти зовнішніх маніпуляцій свідомістю населення України» зазначає: «Порівняно з уже класичними в міжнародній практиці методиками ведення такої війни, російсько-українське протистояння вирізняється певними специфічними ознаками. Вони полягають у тому, що:

- протистояння будується з урахуванням ментальної близькості слов'янських народів - українського і російського;

- обидва народи тривалий в історичному вимірі час існували у спільному культурному просторі;

- у спільній союзній державі активні міграційні процеси сприяли ослабленню ментальних настанов титульних націй республік, культивувалося уявлення про «єдиний радянський народ»;

- проблема ментальності не визнавалася як реальний об'єкт вивчення, не була включена в освітню практику і, таким чином, ментальні засади не були свідомим поведінковим орієнтиром для більшості людей, які здобували освіту в радянських навчальних закладах» [10, с. 220].

Отже, маємо констатувати надзвичайну важливість врахування та використання етнопсихологічного чинника в організації системи протидії ворожим інформаційно-пропагандистським впливам і нагальну необхідність пришвидшити та розширити спектр досліджень у галузі українського менталітету. Навіть у прислів'ях і приказках, які яскраво відображають на побутовому рівні характерні риси української вдачі, можна виділити ті з них, що сприяють виконанню поставленого завдання щодо формування психологічної резистентності.

Такі якості національного характеру, як підозрілість, схильність до відособлення і самостійного ухвалення рішення, певний соціальний егоїзм та інші, їм подібні, прекрасно відповідають умовам існування суспільства на п'ятому рівні розвитку (вказано в попередньому пункті) і за належного підходу можуть привести до кумулятивного позитивного ефректу.

Отже, змістом роботи на третьому напрямі має бути дослідження та культивування тих рис українського національного характеру, які допомагають формувати критичне сприйняття інформації, самостійність мислення і поведінки, прагнення до успіху і конкурентної боротьби.

Висновки і пропозиції. Отже, на основі аналізу психологічних чинників впливу на особистість агресивного інформаційного середовища можна визначити три основні напрями формування в особистості психологічної резистентності до нього - на індивідуальному, соціальному та національному рівнях відповідно.

Водночас варто враховувати наявність у вітчизняній традиції певного перманентного конфллікту між прагненням держави до уніфікації громадян, нівелювання їхніх індивідуальних проявів і природним бажанням людей до самостійності, ініціативи та творчої самореалізації. Крім цього, існує і другий конфлікт - між необхідністю створення ефективної системи протидії ворожому інформаційно-пропагандистському впливу як необхідної умови існування держави і потребою тієї ж держави в підпорядкуванні мас. На нашу думку, ці конфлікти можуть бути врегульовані за допомогою різноманітних громадських організацій, що, як показує досвід останніх п'яти років, українське суспільство створює швидко і використовує максимально ефективно.

\section{Література:}

1. Бек Д., Кован К. Спиральная динамика. Управляя ценностями, лидерством и изменениями в XXI веке. Москва : Открытый мир, 2010. 424 c.

2. Блэк С. Введение в пабликрилейшнз. Ростовна-Дону : Феникс, 1998. 320 с. 
3. Гамаюн M. Homo Unus. T. 1. Москва : Издательские решения, 2016. 655 с.

4. Горкина М., Мамонтов А., Манн И. PR на 100\%. Как стать хорошим менеджером по PR. Москва : Альпина Бизнес Букс, 2009. 248 с.

5. Завадський I. Інформаційна війна - що це таке? Захист інформації. Конфідент. 1996. № 4.

6. Ле Бон Г. Психология масс. Санкт-Петербург : Питер, 2017. 224 с.

7. Лисичкин В., Шелепин Л. Третья мировая информационно-психологическая война. Москва : Академия социальных наук, 1999. URL: http://www.duel.ru/publish/lisichkin/voina. html (дата звернення: 01.07.2019).

8. Остроухов В. Інформаційна безпека, 2010. URL: http://westudents.com.ua/glavy/51894-12nformatsyna-vyna-yak-forma-vedennya- nformatsynogoprotiborstva.html (дата звернення: 01.07.2019).

9. Почепцов Г. Інформаційно-психологічна війна. Москва : Сінтег, 2000. 180 с.

10.Соціокультурні механізми формування ментального імунітету проти зовнішніх маніпуляцій свідомістю населення України : монографія / В. Горовий та ін. ; НАН України, Нац. б-ка України ім. В.І. Вернадського. Київ, 2015. 226 с.

11. Чумиков А., Бочаров М. Связи с общественностью: теория и практика. Москва : Дело, 2006. 552 c.

12.Шпилик C. Інформаційна війна, пропаганда та PR: такі схожі й такі різні. Галицький економічний вісник. Тернопіль : ТНТУ, 2014. Т. 47. № 4. С. $178-188$.

Titiaiev V. M. The main directions of formation of psychological resistance to the influence of aggressive information environment

Based on the analysis of the current level of information-psychological influence on Ukraine by the Russian Federation and relevant scientific developments in this area, the article states the fact that a full-fledged information war is waged against our country, as well as a lack of willingness on the part of the state and society to resist it. On this basis, the urgent need is determined for the creation in Ukraine of a coherent effective system to counter aggressive information impact. The study of modern approaches to determining the structure of the information war made it possible to single out the psychological component in its composition as a direct object of the direction of the efforts of psychological science.

The analysis of this component provided an opportunity to distinguish three groups of psychological factors affecting a person's tendency to be influenced by an aggressive information environment or to resist it. These are individual psychological, social psychological and ethno-psychological factors. The first group includes personal qualities that prompt a person to conformal behavior, the second - factors determined by the level of development of society, and the third - characteristic features of the national mentality.

Based on this classification, in accordance with the above groups of factors, directions have been developed for the formation of psychological resistance of a person to information and propaganda effects and the conditions for their effective implementation. Accordingly, the first direction is the formation of individual psychological resistance, the main content of which is the development of the individual's ability to critical thinking. The second direction - the formation of psychological resistance at the social level - involves, on the one hand, the enlightenment of the state and public organizations to provide citizens with relevant information on the state of development of society and its prospects, and on the other, the reform of state institutions in accordance with the current level of development of society. The third direction is the formation of psychological resistance at the level of national consciousness, and the leading content of the work is supposed to study and cultivate those traits of a national character that help to form a critical perception of information, independent thinking and behavior, the desire for success and competition.

Key words: information war, psychological resistance, conformism, spiral dynamics, national mentality. 